\title{
PENGEMBANGAN PERANGKAT PEMBELAJARAN UNTUK MENINGKATKAN HASIL BELAJAR SISWA MELALUI PELATIHAN STRATEGI BELAJAR MEMBACA PADA POKOK BAHASAN SISTEM PEREDARAN DARAH DI SMA
}

\author{
Wahyuni Puji Astuti ${ }^{1)}$ \\ Mohamad Nur ${ }^{2)}$ \\ Yuni Sri \\ Rahayu ${ }^{2)}$ \\ 1)Mahasiswa Pascasarjana Prodi Pendidikan Sains Universitas Negeri Surabaya \\ 2)Dosen Pascasarjana Prodi Pendidikan Sains Universitas Negeri Surabaya
}

\begin{abstract}
In Indonesia Internationally Standardized School, the teacher are required to use English andcommunication technology in teaching math and science. The use of English, however, often becomes an obstacles for the students to follow the teaching learning process, so the students need to be taught reading strategies which help them to improve their achievement. This research was aimed at: (1) developing teaching learning materials, (2) describing the quality of the teaching learning materials, (3) finding out the implementation of the lesson plan to train reading strategies, (4) finding out how the students use the reading strategies, (5) finding out the students learning achievement both in the product and process, (6) finding out students interest in the implementation of the reading strategies in the teaching and learning process.The researcher developed the teaching learning materials using 4D model and use One Group Pretest-Postest Design during the implementation. The reaserch data were analized using quantitative and qualitative analysis. The teaching learning materials were validated by expert as good, so they can be used in the teaching and learning process. The implementation of the four lesson plans were good. Students reading ability to find out the differences and simillarities was in good category. Students reading ability, and learning the new word using Flash Card, were in good category. Student achievement after the teaching and learning process were improved, including the students interest was in good category.
\end{abstract}

Key Words: Reading strategies, Atudent acheevement

Abstrak: Penyelenggaraan Rintisan Sekolah Bertaraf Internasional, sebagaimana diatur oleh pemerintah melalui UU Sisdiknas Nomor 20 tahun 2005 mewajibkan proses pembelajaran untuk Matematika dan IPA menggunakan bahasa Inggris dan penggunaan TIK. Penggunaan bahan ajar berbahasa Inggris merupakan kendala tersendiri bagi siswa untuk mengikuti proses pembelajaran, sehingga diperlukan upaya untuk mengembangkan sebuah perangkat pembelajaran yang bertujuan untuk mengajarkan strategi belajar membaca guna meningkatkan hasil belajar siswa.Penelitian ini dilakukan dengan tujuan untuk: (1) mengembangkan perangkat pembelajaran, (2) mendeskripsikan kualitas perangkat pembelajaran, (3) mengetahui keterlaksanaan perangkat pembelajaran yang didesain untuk melatihkan strategi belajar membaca, (4) mengetahuiketerampilansiswa dalam menggunakan strategibelajar membaca, (5) mengetahui ketuntasan hasil belajar siswa yang meliputi produk dan proses, dan (6) mengetahui minat siswa terhadap penggunaan strategi belajar membac adalam kegiatan belajar. Perangkat yang dikembangkan menggunakan model pengembangan perangkat $4 D$ sedangkan rancangan penelitian yang dipakai adalah One Group PretestPostest Design sedangkan hasil penelitian dianalisis dengan teknik analisis deskriptif. Perangkat pembelajaran yang telah dikembangkan dalam penelitian ini menurut hasil validasi pakar memiliki kualitas baik, sehingga layak digunakan sebagai perangkat dalam pembelajaran. Keterlaksanaan rata-rata dari keempat RPP ini dikategorikan baik. Keterampilan belajar membaca siswa untuk mencari persamaan dan perbedaan dikategorikan belum tuntas, keterampilan membaca umum baik dan keterampilan belajar kata baru dengan menggunakan Flash Card sangat baik. Ketuntasan belajar siswa meningkat dilihat dari proporsi jawaban benar sebelum pembelajaran dan sesudah pembelajaran. Minat siswa terhadap pembelajaran dikategorikan baik.

Kata kunci: Pengembangan perangkat pembelajaran, strategi belajar membaca. 


\section{PENDAHULU}

Pelaksanaan Rintisan Sekolah Bertaraf Internasional (RSBI) yang merupakan upaya pemerintah untuk meningkatkan mutu lulusan mensyaratkan penggunaan bahan ajar berbahasa Inggris serta kriteria ketuntasan minimal di atas rata-rata sekolah berstandar nasional. Penggunaan bahan ajar dalam bahasa Inggris pada penyelenggaraan Rintisan Sekolah Bertaraf Internasional ini menimbulkan masalah serius karena sebagian besar peserta didik belum terbiasa menggunakan bacaan dalam bahasa Inggris sebagai referensi utama di dalam kegiatan belajar mengajar.

Permasalahan lain yang muncul dengan adanya program RSBI adalah penetapan kriteria ketuntasan minimal lebih tinggi dibandingkan dengan sekolah- sekolah yang hanya menerapkan Standar Nasional Pendidikan. Di sekolah peneliti sendiri, menerapkan kriteria ketuntasan minimal sebesar 75. Pengalaman selama empat tahun pelaksanaan RSBI, data di sekolah peneliti menunjukkan perolehan nilai rata-rata kompetensi dasar sistem peredaran darah mulai tahun pelajaran

2004/2005 sampai dengan 2008/2009 sebesar 68,3. Data tersebut menunjukkan kesenjangan, karena perolehan ketuntasan siswa jauh di bawah kriteria ketuntasan minimal.

Hasil belajar siswa yang kurang (di bawah kriteria ketuntasan minimal) dipengaruhi oleh banyak faktor, salah satunya sebagaimana dituliskan oleh Bradshaw,

1995; Chan, 1991; Smith, 1998 dalam Westwood (2004) dikarenakan adanya kesulitan di dalam belajar. Faktor lain yang juga berperan dalam keberhasilan siswa di dalam pembelajaran adalah minat. Minat merupakan salah satu kunci keberhasilan seseorang dalam mengerjakan sesuatu. Minat siswa dalam belajar merupakan perasaan suka atau ketertarikan terhadap pelajaran yang perlu ditumbuhkan sehingga muncul keinginan untuk dapat menguasai suatu materi pelajaran.

Kesulitan yang dialami siswa tentu saja harus dicarikan jalan keluarnya. Salah satu cara yang dapat dilakukan adalah dengan jalan mengajarkan kepada siswa tentang bagaimana belajar yang baik untuk mengatasi kesulitan belajar dan menyelesaikan tugas sekolah. Mengajarkan bagaimana belajar yang baik, merupakan upaya untuk mengenalkan suatu strategi belajar kepada siswa. Melalui pelatihan strategi belajar diharapkan akan muncul minat siswa dalam pembelajaran.

\section{Tujuan Penelitian}

(1) Mendeskripsikan kualitas perangkat pembelajaran yang dikembangkan dilihat dari hasil validasi pakar yang meliputi silabus, RPP, LKS dan Kunci LKS, Lembar Penilaian dan Kunci Lembar Penilaian serta Buku Ajar Siswa. (2). Mendeskripsikan keterlaksanaan perangkat pembelajaran yang telah dikembangkan untuk melatihkan strategi belajar membaca pada pokok bahasan Sistem
Peredaran Darah.(3). Mendeskripsikan keterampilan siswa dalam menggunakan strategi belajar membaca.(4). Mendeskripsikan ketuntasan hasil belajar siswa yang meliputi produk dan proses, melalui pelatihan strategi belajar membaca. (5) Mendeskripsikan minat siswa terhadap pembelajaran yang dirancang untuk melatihkan strategi belajar membaca.

\section{METODE PENELITIAN}

Jenis penelitian ini adalah penelitian pengembangan dengan menerapkan perangkat pembelajaran yang telah dikembangkan untuk melatihkan strategi belajar membaca sehingga diharapkan dapat meningkatkan hasil belajar siswa pada Kompetensi Dasar Sistem Peredaran Darah.

Perangkat pembelajaran yang dikembangkan meliputi Silabus (Syllabus), RPP (Lesson Plan), LKS (Student Activity), Lembar Penilaian (Assessment Sheet) dan Buku Ajar Siswa (Student Book) yang didesain untuk melatihkan strategi belajar membaca. Perangkat pembelajaran tersebut dicoba diterapkan dalam pembelajaran di kelas dan dilakukan analisis terhadap proses beserta hasilnya.

\section{Subyek Penelitian}

Subyek pada penelitian ini meliputi dua hal, pertama adalah perangkat yang dikembangkan. Subyek kedua adalah siswa yang dikenai uji coba terhadap perangkat yang telah dikembangkan. Subjek kedua yang dipilih dalam penelitian pendahuluan (ujicoba I) ini adalah siswa kelas XI SMAN 3 Madiun sebanyak 12 orang dari 3 kelas yang berbeda, sehingga setiap kelas diambil 4 orang anak secara acak berdasarkan nilai harian siswa. Adapun subyek untuk kepentingan ujicoba II adalah siswa satu kelas pada XI IPA 3 SMAN 3 Madiun sebanyak 27 siswa.

\section{Prosedur Penelitian}

Penelitian pengembangan ini dilaksanakan melalui dua tahapan, yaitu pengembangan perangkat dan uji coba (implementasi) perangkat pembelajaran di kelas.

\section{Pengembangan Perangkat Pembelajaran}

Pengembangan perangkat pembelajaran dalam penelitian ini mengacu pada pengembangan perangkat yang dituliskan oleh Thiagarajan, Semmel, dan Semmel (1974), yang dikenal dengan model 4-D (four D model). Model ini terdiri dari 4 tahap, yaitu Define, Design, Develop, dan Disseminate.Pada penelitian ini hanya dilakukan 3 tahapan saja, yaitu Define, Design, dan Develop. Hal ini dikarenakan keterbatasan waktu dan faktor pendukung yang lain.Adapun ketiga tahapan tersebut disederhanakan melalui bagan yang disajikan dalam Diagram1 Diagram Alir Pengembangan Perangkat Pembelajaran. 


\section{Ujicoba (implementasi) Perangkat Pembelajaran}

Uji coba atau implementasi perangkat pembelajaran ini dilakukan dua kali.Subjek uji coba I adalah siswa kelas XI IPA SMAN 3 Madiun, sebanyak 12 siswa yang diambil dari 3 kelas. Uji coba perangkat pembelajaran dilaksanakan pada semester ganjil tahun pelajaran 2010/2011 dengan melibatkan tiga orang pengamat, seorang guru mengamati aspek afektif siswa selama mengikuti proses pembelajaran dan dua guru yang lain mengamati keterlaksanaan perangkat pembelajaran. Sebagai guru model adalah peneliti sendiri.Kegiatan ujicoba I ini bertujuan untuk memperoleh data mengenai keterlaksaaan perangkat pembelajaran yang telah dikembangkan, hasil belajar siswa, keterampilan membaca siswa serta minat siswa sebagai dasar untuk melakukan revisi dan penyempurnaan perangkat pembelajaran tersebut pada uji coba II.

Uji coba II dilaksanakan setelah uji coba I selesai dilaksanakan dan dilaporkan keterlaksanaannya untuk mendapatkan masukan demi perbaikan kualitas perangkat yang telah dikembangkan. Adapun subyek pada uji coba II ini meliputi perangkat pembelajaran yang telah mengalami perbaikan berdasarkan masukan dari para ahli serta berdasarkan hasil keterlaksanaan selama uji coba I dan siswa kelas XI IPA 3 sebanyak 27 siswa.

Implementasi perangkat pada kegiatan uji coba II ini dilaksanakan pada semester genap tahun pelajaran 2010/2011, dengan melibatkan 2 orang guru pengamat keterlaksanaan RPP dan 4 orang guru yang akan mengamati aspek afektif siswa selama kegiatan pembelajaran berlangsung. Rancangan penelitian pada kegiatan ujicoba I dan II ini menggunakan rancangan One Group Pretest-Posttest Design (Arikunto, 1998), yang digambarkan sebagai berikut. $\mathrm{O}_{1} \quad \mathrm{X} \quad \mathrm{O}_{2}$

Keterangan :

$$
\begin{array}{ll}
\mathrm{O} 1 & =\text { Uji awal } \\
\mathrm{X} & =\text { Implementasi perangkat pembelajaran } \\
\mathrm{O} 2 & =\text { Uji akhir }
\end{array}
$$

\section{Teknik Analisis Data}

\section{Analisis validasi}

Data hasil validasi perangkat pembelajaran akan dianalisis menggunakan analisis deskriptif kualitatif dengan cara menghitung rata-rata skor penilaian oleh dua orang validator dengan menggunakan Instrumen 01. Interval skor 1 sampai dengan 4, dengan kriteria sebagai berikut:1 = kurang, 2= cukup, 3 = baik dan $4=$ baik sekali Selanjutnya rata-rata di atas akan dikonversi menggunakan ketentuan sebagai berikut:

\begin{tabular}{|ll|l|}
\hline $1,00-1,99$ & $:$ & Kurang \\
$2,00-2,99$ & $:$ & Cukup \\
$3,00-3,49$ & $:$ & Baik \\
$3,50-4,00$ & $:$ & Baik Sekali \\
\hline
\end{tabular}

\section{Analisis keterlaksanaan Rencana Pelaksanaan Pembelajaran (RPP)}

Keterlaksanaan RPP dianalisis menggunakan analisis deskriptif kualitatif dengan persentase. Data hasil pengamatan yang diberikan oleh dua orang pengamat dengan menggunakan Instrumen 02 tentang keterlaksanaan rencana pelajaran akan dicari persentase mengenai terlaksanannya tahapan-tahapan dalam RPP yang dilakukan guru selama proses pembelajaran berlangsung.Secara umum perhitungan persentase keterlaksanaan RPP (P) adalah sebagai berikut:

\section{$\mathbf{P}=\frac{\text { Jumlah tah apan RPP yang berhasil dil aksanakan }}{\text { To }} \mathbf{1 0 0 \%}$ Totalkeseluruhan tahapan RPP}

Kriteria keterlaksanaan RPP adalah sebagai berikut:

$25 \% \leq \mathrm{P}<50 \%$
$50 \% \leq \mathrm{P}<75 \%$
$75 \% \leq \mathrm{P}<100 \% \quad$ terlaksana kurang
$0 \% \leq \mathrm{P} \quad$ terlaksana baik
$25 \% \quad=$ terlaksana sangat baik

(Budiningarti dalam Latjompoh, 2000)

Untuk menentukan reliabilitas Instrumen 02 Pengamatan Keterlaksanaan Rencana Pembelajaran, hasil pengamatan yang dilakukan oleh pengamat dihitung kecocokannya dengan menggunakan rumus berikut ini.

\section{$R=\frac{A}{D+A} \times 100 \%$}

Keterangan:

$\mathrm{R}=$ Reliabilitas Instrumen

$\mathrm{A}=$ Frekuensi kecocokan antara dua pengamat

$\mathrm{D}=$ Frekuensi ketidakcocokan antara dua pengamat

Instrumen dikatakan reliabel bila nilai reliabilitasnya $\geq$ 0,75 (Borich, 1994).

Adapun kualitas keterlaksanaan RPP tersebut dinilai dari skor keterlaksanaan pada setiap fase dalam kegiatan pembelajaran yang diberikan oleh dua orang pengamat dan dirata-rata. Hasil rata-rata akan dikonversi dengan ketentuan kategori keterlaksanaan sebagai berikut:

$$
\begin{array}{lll}
0.00-1.99 & : & \text { Tidak Baik } \\
2.00-2.99 & : & \text { Kurang Baik } \\
3.00-3.49 & : & \text { Baik } \\
3.50-4.00 & : & \text { Sangat Baik }
\end{array}
$$

\section{Analisis ketuntasan hasil belajar}

a. Hasil Belajar

Hasil belajar siswa ditentukaan penilaian acuan patokan dan dilakukan analisis deskriptif kuantitatif. Skor yang diperoleh siswa melalui tes hasil belajar akan digunakan untuk ketuntasan individu terhadap tujuan yang telah ditetapkan. Ketuntasan individual dinyatakan dengan ketentuan ketercapaian indikator atau tujuan pembelajaran di atas $65 \%$ dari seluruh indikator pada kompetensi dasar Sistem Peredaran Darah. 
Selanjutnya butir soal yang ada pada Tes Hasil Belajar akan divalidasi dengan dua cara, yaitu untuk validasi isi butir soal didapatkan dari hasil validasi yang dilakukan oleh pakar. Sedangkan yang kedua untuk mengetahui validitas setiap butir soal dilakukan penghitungan sensitifitas butir soal untuk mengetahui sejauh mana tiap butir soal mampu mengukur efek-efek pembelajaran.

Penghitungan sensitifitas butir soal menggunakan rumus sebagai berikut:

$\mathrm{S}=\frac{R a \cdot R b}{T}$

(Grounlund, 1985)

Dimana:

$\mathrm{S}=$ Sensitivitas butir soal

$\mathrm{Ra}=$ Jumlah siswa yang menjawab benar pada tes akhir

$\mathrm{Rb}=$ Jumlah siswa yang menjawab benar pada tes awal

$\mathrm{T}=$ Jumlah siswa yang mengikuti tes

Indeks butir soal yang efektif terdapat antara 0,00 sampai 1,00. Nilai posotif yang lebih besar menyatakan butir soal yang lebih besar kepekaanya terhadap efek-efek pembelajaran. Butir yang mempunyai sensitivitas $\geq 0.30$, maka butir soal tersebut peka terhadap efek-efek pembelajaran (Aiken, 1997).

\section{b. Analisis Tes Keterampilan Membaca}

Data tes keterampilan membaca yang diujikan adalah keterampilan membaca umum meliputi mengidentifikasi topic, mencari unsur-unsur pendukung dan mengidentifikasi ide pokok. Data tes keterampilan membaca akan dianalisis menggunakan teknik analisis deskriptif kuantitatif dengan cara mencari skor total yang diperoleh siswa dibagi dengan skor maksimal dari masing-masing langkah atau kriteria dalam menggunakan keterampilan membaca umum, kemudian dikalikan 100.

Keterampilan membaca mencari persamaan dan perbedaan serta belajar kata baru dengan menggunakan Flash Card diperoleh dari Tes Hasil Belajar baik produk maupun proses. Siswa dikatakan terampil dalam menggunakan keterampilan membaca apabila skor yang diperoleh adalah $\geq 75$.

\section{c. Ketercapaian Kompetensi Dasar}

Ketercapaian Kompetensi Dasar siswa dihitung dengan menggunakan rumus:

$$
\text { Ketercapaian KD }=\frac{\sum \text { Indikator yang tuntas }}{\sum \text { Indikator dalam } K D} \times 100 \%
$$

\section{Analisis Data Hasil Angket}

Analisis data angket minat pada Instrumen 05 akan dilakukan analisis deskriptifkualitatif yang dikuantifikasikan dengan ketentuan sebagai berikut.

a. Menggolongkan pernyataan dalam angket minat siswa terhadap pembelajaran berdasarkan kriteria positif atau negatif sebagaimana berikut
No. angket positif: $1,2,3,5,6,7,11,12,13,14,15$, $16,18,19,20,21,22,23,24,27$, $28,29,30,32,33,34$.

No. angket negatif: 4, 8, 9, 10, 17, 25, 26, 31 .

b. Untuk pernyataan dengan kriteria positif:

Sangat tidak setuju $=1$

Tidak setuju $\quad=2$

Ragu-ragu $\quad=3$

Setuju $\quad=4$

Sangat setuju $\quad=5$

c. Untuk pernyataan dengan kriteria negatif:

Sangat tidak setuju $=5$

Tidak setuju $\quad=4$

Ragu-ragu $\quad=3$

Setuju $\quad=2$

Sangat setuju $\quad=1$

Skor minat dihitung dengan menggunakanrumus:

\section{¿Skarperolehan tlapkategori $\sum$ Butir angket tiap kategori}

d. Kategori minat diperoleh dari rata-rata skor minat dengan ketentuan:

$1,00-1,49=$ tidak baik; $1,50-2,49=$ kurang baik;

2,50-3,49= cukup baik; $3,50-4,49=$ baik dan 4,50 $5,00=$ sangat baik.

\section{HASIL DAN PEMBAHASAN}

\section{Pengembangan Perangkat Pembelajaran}

Perangkat pembelajaran yang berhasil dikembangkan dalam penelitian ini meliputi: 1) Silabus (Syllabus), 2) Rencana Pelaksanaan Pembelajaran (Lesson Plan), 3) Lembar Kegiatan Siswa (StudentActivity), 4) Lembar Penilaian (Assessment Sheet) dan 5) Buku Ajar Siswa (Student Book).

Kualitas perangkat pembelajaran berdasarkan hasil validasi pakar dapat dilihat pada tabel berikut:

Tabel 1: Kualitas Perangkat Pembelajaran

\begin{tabular}{|l|l|l|}
\hline No. & \multicolumn{1}{|c|}{ Perangkat } & \multicolumn{1}{|c|}{ Hasil Validasi } \\
\hline 1. & Silabus & 3,47 (Baik) \\
\hline 2. & $\begin{array}{l}\text { Rencana Pelaksanaan } \\
\text { Pembelajaran }\end{array}$ & 3,11 (Baik) \\
\hline 3. & Lembar Kegiatan Siswa & 3,47 (Baik) \\
\hline 4. & Lembar Penilaian & Valid dengan revisi kecil \\
\hline 5. & Buku Ajar Siswa & 3,33 (Baik) \\
\hline
\end{tabular}

\section{Keterlaksanaan Perangkat Pembelajaran}

Data keterlaksanaan perangkat pembelajaran, dalam hal ini keterlaksanaan Rencana Pelaksanaan Pembelajaran (RPP) diperoleh melalui pengamatan tabel 2: 
Tabel 2: Keterlaksanaan dan Reliabilitas Instrumen RPP

\begin{tabular}{|l|l|c|c|c|c|c|c|}
\hline \multirow{2}{*}{ No } & \multirow{2}{*}{ Aspek yang Diamati } & \multicolumn{4}{|c|}{ Rata-rata Skor } & Skor Rata- & \multirow{2}{*}{ Kategori } \\
\cline { 3 - 8 } & & $\operatorname{Pr} 01$ & $\operatorname{Pr} 02$ & $\operatorname{Pr} 03$ & $\operatorname{Pr} 04$ & 3,7 & Sangat Baik \\
\hline 1 & Pendahuluan & 3,7 & 3,8 & 3,6 & 3,7 & 3,7 & Sangat Baik \\
\hline 2 & Kegiatan Inti & 3,8 & 3,8 & 3,3 & 3,5 & 3,6 & Sangat Baik \\
\hline 3 & Penutup & 3,0 & 4,0 & 3,0 & 4,0 & 3,5 & Sangat Baik \\
\hline \multicolumn{2}{|l|}{ Keterlaksanaan (\%) } & 100 & 100 & 100 & 100 & 100 & Reliabel \\
\hline \multicolumn{2}{|l|}{ Reliabilitas (\%) } & 87 & 84 & 86 & 81 & 84,5 & \\
\hline
\end{tabular}

Keterangan:
Pr. 01 : Pertemuan 01
Pr. 02 : Pertemuan 02
Pr. 03 : Pertemuan 03
Pr 04 : Pertemuan 04

Berdasarkan tabel di atas terlihat bahwa keterlaksanaan RPP sangat baik, karena semua fase dalam RPP dapat dilaksanakan dengan kategori baik.

\section{Hasil Belajar Siswa}

1. Hasil belajar

Hasil belajar siswa yang meliputi produk dan proses dapat dilihat pada tabel berikut ini:

Tabel 3: Ketuntasan dan Sensitivitas Tes Hasil Belajar Produk:

\begin{tabular}{|c|c|c|c|c|c|c|c|c|}
\hline \multicolumn{2}{|c|}{ Nomor } & \multirow[b]{2}{*}{ Tujuan Pembelajaran } & \multirow{2}{*}{$\begin{array}{l}\text { No. Butir } \\
\text { Soal }\end{array}$} & \multicolumn{5}{|c|}{ Ujicoba II } \\
\hline RPP & $\mathrm{TP}$ & & & \multicolumn{2}{|c|}{ pButir Soal } & Sensitivitas & pTP & $\begin{array}{l}\text { Ketuntasan } \\
\text { TP } \mathrm{p} \succeq 5 \%\end{array}$ \\
\hline 01 & 1 & Siswa dapat menyebutkan komposisi & $\begin{array}{l}1 \\
2\end{array}$ & 0,41 & 0,89 & $\begin{array}{l}0,48 \\
0,59\end{array}$ & 0,80 & Tuntas \\
\hline 01 & 2 & $\begin{array}{l}\text { Siswa dapat mengidentifikasi } \\
\text { karakteristik masing-masing } \\
\text { komponen penyusun darah. }\end{array}$ & $\begin{array}{l}3 \\
4 \\
5 \\
6\end{array}$ & $\begin{array}{l}0,22 \\
0,33 \\
0,56 \\
0,15\end{array}$ & $\begin{array}{l}0,74 \\
0,93 \\
0,89 \\
0,78\end{array}$ & $\begin{array}{l}0,52 \\
0,59 \\
0,33 \\
0,63\end{array}$ & 0,83 & Tuntas \\
\hline 01 & 3 & $\begin{array}{l}\text { Siswa dapat mendeskripsikan fungsi } \\
\text { masing-masing komponen penyusun } \\
\text { darah. }\end{array}$ & $\begin{array}{c}7 \\
8 \\
9 \\
10\end{array}$ & $\begin{array}{l}0,59 \\
0,26 \\
0,59 \\
0,33\end{array}$ & $\begin{array}{l}0,96 \\
0,93 \\
0,93 \\
0,70\end{array}$ & $\begin{array}{l}0,37 \\
0,67 \\
0,33 \\
0,37\end{array}$ & 0,88 & Tuntas \\
\hline 01 & 4 & $\begin{array}{l}\text { Siswa dapat menjelaskan aturan } \\
\text { penggolongan darah sistem } \mathrm{ABO} \text {. }\end{array}$ & $\begin{array}{l}11 \\
12 \\
14\end{array}$ & $\begin{array}{l}0,52 \\
0,48 \\
0,30\end{array}$ & $\begin{array}{l}0,93 \\
0,85 \\
0,81\end{array}$ & $\begin{array}{l}0,41 \\
0,37 \\
0,52\end{array}$ & 0,81 & Tuntas \\
\hline 01 & 5 & $\begin{array}{l}\text { Siswa dapat menjelaskan manfaat } \\
\text { donor darah. }\end{array}$ & 13 & 0,41 & 0,81 & 0,41 & 0,86 & Tuntas \\
\hline 01 & 7 & $\begin{array}{l}\text { Siswa dapat menyebutkan ruangan- } \\
\text { ruangan jantung beserta karakteristik } \\
\text { darah yang ada di dalamnya }\end{array}$ & $\begin{array}{l}16 \\
23 \\
33\end{array}$ & $\begin{array}{l}0,48 \\
0,30 \\
0,32\end{array}$ & $\begin{array}{l}0,89 \\
0,89 \\
0,81\end{array}$ & $\begin{array}{l}0,41 \\
0,59 \\
0,52\end{array}$ & 0,88 & Tuntas \\
\hline 02 & 8 & $\begin{array}{l}\text { Siswa dapat menyebutkan nama- } \\
\text { nama pembuluh darah utama beserta } \\
\text { karakteristik darah yang ada di } \\
\text { dalamnya }\end{array}$ & $\begin{array}{l}15 \\
17 \\
18 \\
19 \\
20 \\
21\end{array}$ & $\begin{array}{l}0,44 \\
0,48 \\
0,33 \\
0,44 \\
0,30 \\
0,44\end{array}$ & $\begin{array}{l}0,81 \\
0,85 \\
0,78 \\
0,81 \\
0,63 \\
0,93\end{array}$ & $\begin{array}{l}0,37 \\
0,37 \\
0,44 \\
0,37 \\
0,33 \\
0,48\end{array}$ & 0,78 & Tuntas \\
\hline 02 & 10 & $\begin{array}{l}\text { Siswa dapat mendeskripsikan } \\
\text { peredaran darah pada manusia }\end{array}$ & $\begin{array}{l}22 \\
34\end{array}$ & $\begin{array}{l}0,52 \\
0,13\end{array}$ & $\begin{array}{l}0,89 \\
0,69\end{array}$ & $\begin{array}{l}0,37 \\
0,44\end{array}$ & 0,85 & Tuntas \\
\hline 04 & 14 & $\begin{array}{l}\text { Siswa dapat menjelaskan mekanisme } \\
\text { pembekuan darah }\end{array}$ & 27 & 0,26 & 0,70 & 0,44 & 0,70 & Tuntas \\
\hline 04 & 15 & $\begin{array}{l}\text { Siswa dapat menjelaskan pentingnya } \\
\text { peristiwa pembekuan darah }\end{array}$ & 35 & 0,35 & 0,74 & 0,44 & 0,74 & Tuntas \\
\hline 04 & 16 & $\begin{array}{l}\text { Siswa dapat menjelaskan struktur dan } \\
\text { fungsi sistem limfa }\end{array}$ & $\begin{array}{l}28 \\
29 \\
30\end{array}$ & $\begin{array}{l}0,11 \\
0,41 \\
0,30\end{array}$ & $\begin{array}{l}0,70 \\
0,78 \\
0,81\end{array}$ & $\begin{array}{l}0,59 \\
0,37 \\
0,52\end{array}$ & 0,77 & Tuntas \\
\hline 04 & 17 & $\begin{array}{l}\text { Siswa dapat menjelaskan istilah pada } \\
\text { kelainan sistem peredaran darah }\end{array}$ & $\begin{array}{l}26 \\
31\end{array}$ & $\begin{array}{l}0,44 \\
0,37\end{array}$ & $\begin{array}{l}0,89 \\
0,78\end{array}$ & $\begin{array}{l}0,44 \\
0,41\end{array}$ & 0,83 & Tuntas \\
\hline & & Proporsi dan sensitivitas rata-rata & & 0,37 & 0,82 & 0,45 & 0,81 & Tuntas \\
\hline
\end{tabular}

Keterangan: Q1 = Uji Awal (pretest) Q2 = Uji akhir (post test) $\mathrm{pTP}=$ proporsi Tujuan Pembelajaran 
Tabel 4: Ketuntasan dan Sensitivitas Tes Hasil Belajar

Ket: $\mathrm{p} 1=$ mengidentifikasi topik Proses

P2 = mencari elemen-elemen pendukung

P3 = mengidentifikasi ide pokok

\begin{tabular}{|c|c|c|c|c|c|c|c|c|}
\hline \multicolumn{2}{|c|}{ Nomor } & \multirow{3}{*}{ Tujuan Pembelajaran } & \multirow{3}{*}{$\begin{array}{l}\text { No. Butir } \\
\text { Soal }\end{array}$} & \multicolumn{5}{|c|}{ Ujicoba II } \\
\hline \multirow{2}{*}{ RPP } & \multirow{2}{*}{$\mathrm{TP}$} & & & \multicolumn{2}{|c|}{ pButir Soal } & \multirow{2}{*}{ Sensitivitas } & \multirow{2}{*}{$\mathrm{pTP}$} & \multirow{2}{*}{$\begin{array}{l}\text { Ketuntasan TP } \\
\mathrm{p} \succeq 65 \%\end{array}$} \\
\hline & & & & Q1 & Q2 & & & \\
\hline 02 & 9 & $\begin{array}{l}\text { Siswa dapat memban-dingkan struktur dan fungsi } \\
\text { arteri, vena dan kapiler }\end{array}$ & 32 & 0,09 & 0,83 & 1,00 & 0,83 & Tuntas \\
\hline 03 & 11 & $\begin{array}{l}\text { Siswa dapat meng-analisis hubungan antara } \\
\text { aktivitas fisik terhadap kecepatan denyut jantung }\end{array}$ & $\begin{array}{l}24 \\
25\end{array}$ & $\begin{array}{l}0,59 \\
0,37\end{array}$ & $\begin{array}{l}0,93 \\
0,78\end{array}$ & $\begin{array}{l}0,33 \\
0,41\end{array}$ & 0,87 & Tuntas \\
\hline \multirow[t]{6}{*}{03} & \multirow[t]{6}{*}{12} & $\begin{array}{l}\text { Siswa dapat menye-lidiki pengaruh ak-tivitas fisik } \\
\text { terhadap kecepatan denyut jantung }\end{array}$ & & & & & \multirow{6}{*}{0,88} & \multirow{6}{*}{ Tuntas } \\
\hline & & Siswa dapat mem-buat rumusan masalah & 38 & 0,25 & 0,72 & 0,52 & & \\
\hline & & Siswa dapat meru-muskan hipotesis & 39 & 0,06 & 0,69 & 0,48 & & \\
\hline & & Siswa dapat menentukan variabel penelitian & 40 & 0,20 & 0,85 & 0,89 & & \\
\hline & & $\begin{array}{l}\text { Siswa dapat mem-buat analisis mengenai } \\
\text { pengaruh aktifitas fisik dan pososi tubuh } \\
\text { terhadap kecepatan denyut jantung }\end{array}$ & 41 & 0,25 & 0,88 & 0,89 & & \\
\hline & & Siswa dapat menyimpulkan hasil penelitian & 42 & 0,24 & 0,67 & 0,41 & & \\
\hline 04 & 18 & $\begin{array}{l}\text { Siswa dapat menganalisis faktor yang } \\
\text { menyebabkan munculnya kelainan pada sistem } \\
\text { peredaran darah serta gejala yang } \\
\text { ditimbulkannya }\end{array}$ & $\begin{array}{l}36 \\
37\end{array}$ & $\begin{array}{l}0,52 \\
0,22\end{array}$ & $\begin{array}{l}0,81 \\
0,86\end{array}$ & $\begin{array}{l}0,41 \\
0,89\end{array}$ & 0,83 & Tuntas \\
\hline & & Proporsi dan sensitivitas rata-rata & & 0,28 & 0,80 & 0,67 & 0,85 & Tuntas \\
\hline
\end{tabular}

Berdasarkan Tabel 3 dan 4 di atas, hasil belajar produk dan proses semuanya mengalami ketuntasan

Hasil belajar psikomotor dan afektif dikategorikan tuntas, karena ketercapaian setiap indikator pada KD Sistem Peredaran Darah mencapai 99\% untuk hasil belajar psikomotor dan $100 \%$ untuk hasil belajar afektif.

2. Keterampilan Membaca Siswa

Keterampilan membaca siswa dapat dilihat melalui dua faktor. Pertama include di dalam Tes Hasil Belajar baik produk maupun proses dan kedua dilihat dari Tes Keterampilan Membaca Umum yang meliputi: mengidentifikasi topik, mencari elemen-elemen pendukung, serta mengidentifikasi ide pokok dari statu bacaan. Keterampilan Membaca Umum siswa dapat dilihat pada Tabel berikut ini.

Tabel 5: Proporsi Ketercapaian Keterampilan Membaca Umum

\begin{tabular}{|c|c|c|c|c|c|}
\hline \multirow{2}{*}{$\begin{array}{c}\text { Aspek } \\
\text { Keterampilan } \\
\text { Membaca }\end{array}$} & \multicolumn{4}{|c|}{ Ujicoba II } & \multirow{2}{*}{ Rata -rata } \\
\cline { 2 - 5 } & Parg.1 & Parg.2 & Parg.3 & $\begin{array}{l}\text { Par. } \\
4\end{array}$ & \\
\hline$(\mathrm{p} 1)$ & 0,83 & 0,80 & 0,89 & 0,80 & 0,83 \\
\hline$(\mathrm{p} 2)$ & 0,90 & 0,87 & 0,70 & 0,73 & 0,80 \\
\hline$(\mathrm{p} 3)$ & 0,76 & 0,78 & 0,96 & 0,78 & 0,82 \\
\hline Rata-rata & 0,83 & 0,77 & 0,85 & 0,71 & 0,79 \\
\hline
\end{tabular}

\section{t Siswa}

Data mengenai minat siswa terhadap pembelajaran untuk melatihkan strategi belajar membaca, secara ringkas ditampilkan pada tabel berikut ini.

Tabel 6: Minat Siswa terhadap Pembelajaran

\begin{tabular}{|c|l|c|c|c|c|}
\hline \multirow{2}{*}{ No } & \multirow{2}{*}{ Kondisi } & \multicolumn{4}{|c|}{ Ujicoba II } \\
\cline { 3 - 5 } & & \multicolumn{2}{|c|}{ Kriteria } & \multirow{2}{*}{$\begin{array}{c}\text { Rata- } \\
\text { rata }\end{array}$} & \multirow{2}{*}{ Kategori } \\
\cline { 3 - 5 } & Positif & Negatif & \\
\hline 1 & Perhatian & 4,05 & 3,94 & 4,00 & Baik \\
\hline 2 & Relevansi & 4,21 & 4,30 & 4,25 & Baik \\
\hline 3 & Percaya diri & 4,17 & 3,39 & 3,78 & Baik \\
\hline 4 & Kepuasan & 4,12 & 3,93 & 4,02 & Baik \\
\hline
\end{tabular}

\section{Hasil dan Kualitas Perangkat Pembelajaran}

Berdasarkan hasil pada tahap validasi ahli menunjukkan bahwa perangkat pembelajaran untuk melatihkan strategi belajar membaca pada materi sistem peredaran darah ditinjau dari indikator format, bahasa, isi, dan/atau ilustrasi dikategorikan baik dan dapat digunakan dengan revisi kecil. Hal ini ditunjukkan dengan ratarata penilaian dari para validator terhadap Silabus, RPP, LKS dan Buku Ajar Siswadi atas 3. Sedangkan hasil penilaian para validator terhadap LP secara umum adalah valid, dapat dipahami, dan dapat digunakan dengan revisi kecil.

Predikat baik diperoleh karena sebelum memulai kegiatan pengembangan perangkat ini, peneliti memutuskan untuk mengadopsi model pengembangan perangkat 4-D oleh Thiagarajan dkk sebagai acuan atau pedoman untuk mengembangkan perangkat 
pembelajaran yang disesuaikan dengan tujuan guru di dalam kegiatan pengembangan, yaitu untuk menghasilkan suatu perangkat pembelajaran yang didesain sebagai upaya meningkatkan hasil belajar siswa melalui pelatihan strategi belajar membaca. Hal ini sejalan dengan pendapat Braxton et al (1995) dalam Qureshi (2004), bahwa model-model pengembangan perangkat menyediakan kerangka kerja untuk menghasilkan pengajaran yang sistematik, di mana elemen-elemen penting dari proses pendesainan pembelajaran digabungkan termasuk analisis dalam menentukan tujuan.

\section{Keterlaksanaan Rencana Pelaksanaan Pembelajaran}

Kualitas pelaksanaan RPP berkisar antara 3,00 sampai 4,00, dengan kategori sangat baik. Keterlaksanaan RPP ini didukung oleh ketersediaan perangkat pembelajaran yang telah dikembangkan oleh peneliti, seperti RPP, LKS, media pengajaran berupa slide power point serta Buku Ajar Siswa. Hal ini sesuai dengan pendapat Nur (1998) yang menyatakan bahwa, salah satu faktor yang mempengaruhi kualitas pembelajaran adalah tersedianya perangkat pembelajaran yang disertaidengan komitmen tinggi untuk melaksanakannya dalam setiap pembelajaran.

Selain kelengkapan perangkat pembelajaran, sarana dan prasarana yang tersedia di sekolah peneliti sangat mendukung keterlaksanaan pembelajaran sesuai dengan perencanaan. Keberhasilan pelaksanaan pembelajaran juga tidak terlepas dari ketepatan pemilihan model pembelajaran yang digunakan sebagai model untuk melatihkan strategi belajar membaca, yaitu menggunakan model pengajaran langsung. Dasar pemilihan model pengajaran langsung ini adalah peneliti hendak melatihkan suatu strategi yang akan dilatihkan langkah demi langkah, dengan memperhatikan sumber daya waktu yang terbatas. Hal ini didukung dengan pendapat Bligh (2000) dalam Slavin (2008), bahwa cara paling efektif dan efisien untuk mengajari siswa adalah agar guru menyajikan informasi, kemampuan atau konsep secara langsung. Lebih lanjut Gersten, Tailor \& Graves (1999); Gunter, Estes \& Schwab (2003) dalam Slavin (2008), mengungkapkan bahwa penggunaan model pengajaran langsung adalah untuk menyampaikan informasi langsung kepada siswa, dengan menata waktu pelajaran untuk mencapai beberapa sasaran yang telah ditetapkan dengan baik yang harus dikuasai oleh semua siswa.

\section{Ketuntasan Hasil Belajar Siswa}

Berdasarkan hasil analisis statistik deskriptif kuantitatif, Ketuntasan hasil belajar siswa menunjukkan satu tujuan pembelajaran produk dan satu tujuan pembelajaran proses tidak tuntas. Ketidaktuntasan pada kedua tujuan pembelajaran itu telah diantisipasi dengan cara memperbaiki kualitas pembelajaran, menambahkan pengalaman belajar serta memperjelas maksud butir soal pada Lembar Penilaian. Perbaikan pada proses pembelajaran maupun perbaikan butir soal, ternyata berhasil mengatasi ketidaktuntasan dua tujuan pembelajaran, sehingga pada pelaksanaan implementasi seluruh tujuan pembelajaran tercapai ketuntasannya.

Hasil belajar siswa menunjukkan peningkatan sebagaimana ditampilkan pada Tabel 3 dan 4, dimana proporsinya sebesar 0,33 dan uji akhir sebesar 0,81 . Meningkatnya hasil belajar belajar siswa ini karena di dalam menyelesaikan tugas-tugas sekolah, siswa dilatihkan suatu strategi belajar membaca dengan menggunakan model pembelajaran langsung, sehingga kemampuan siswa dalam menggunakan strategi belajar membaca yang dikategorikan baik ini memberikan sumbangan bagi peningkatan hasil belajar siswa. Hal ini sejalan dengan penjelasan Slavin (2008), bahwa strategi yang digunakan guru untuk memindahkan informasi kepada siswa dengan cara yang paling memungkinkan membantu siswa memahami, menyatukan dan menggunakan konsep dan kemampuan baru.

\section{Keterampilan Membaca Siswa}

Berdasarkan hasil analisis deskriptif kuantitaf pada Tabel 5 menunjukkan bahwa skor rata-rata siswa sebesar 82, sehingga dikategorikan baik. Keterampilan membaca yang dilatihkan dan dikuasai dengan baik ini memberikan kontribusi bagi keberhasilan siswa dalam menyelesaikan tugas-tugas sekolah serta sebagai modal untuk menguasai konsep yang pada bahan ajar sehingga dapat dikatakan mampu meningkatkan hasil belajar siswa pada kompetensi dasar sistem peredaran darah.

\section{Minat Siswa}

Hasil analisis minat siswa dalam pembelajaran sebagaimana ditampilkan pada Tabel 6 , bahwa rata-rata minat siswa terhadap pembelajaran ini dengan kategori baik. Hal ini sejalan dengan apa yang dituliskan Nur (2008) pada bukunya yang berjudul Pemotivasian Siswa untuk Belajar, bahwa mempresentasikan materi pelajaran dengan cara yang menarik (termasuk mengajarkan suatu strategi untuk mempermudah siswa dalam belajar) akan memuaskan siswa, sehingga membangkitkan rasa ingin tahu siswa dan pada akhirnya akan meningkatkan minat siswa terhadap pembelajaran.

Berdasarkan pembahasan dari awal hingga akhir, dapat dikatakan bahwa penelitian ini berhasil mengembangkan sebuah perangkat pembelajaran yang didesain dengan tujuan untuk meningkatkan hasil belajar siswa melalui pengajaran strategi belajar membaca untuk mengatasi kesulitan siswa dalam penggunaan bahan ajar berbahasa Inggris. Hasil validasi dua orang pakar di bidang pengembangan perangkat menyatakan bahwa perangkat yang dikembangkan oleh peneliti, sesuai untuk mengajarkan strategi belajar membaca pada pokok bahasan Sistem 
Peredaran Darah.

Faktor kedua yang ikut menunjang keberhasilan tujuan penelitian ini adalah keterlaksanaan perangkat yang diimplementasikan di kelas. Pembelajaran yang dilaksanakan guru, sesuai dengan sintaks yang akan memandu guru untuk melatihkan strategi belajar membaca, selain itu juga sesuai untuk memfasilitasi siswa dalam berlatih menggunakan strategi belajar membaca.

Faktor berikutnya adalah keterampilan siswa dalam menggunakan strategi belajar membaca yang telah dilatihkan selama proses pembelajaran. Data empiris mengenai keterampilan siswa dalam menggunakan strategi belajar membaca pada penelitian ini, baik strategi belajar membaca komprehensif, mencari persamaan dan perbedaan, strategi belajar membaca kata baru dengan menggunakan Flash Card, maupun strategi belajar membaca umum yang meliputi mengidentifikasi topik, mencari unsur-unsur pendukung serta mengidentifikasi ide pokok dikategorikan baik.

\section{SIMPULAN}

Berdasarkan pengembangan perangkat pembelajaran dengan menggunakan model 4-D, dihasilkan perangkat pembelajaran untuk melatihkan strategi belajar membacapada materi sistem peredaran darah.Perangkat pembelajaran tersebut terdiri dari Silabus, Rencana Pelaksanaan Pembelajaran (RPP), Lembar Kerja Siswa (LKS), Lembar Penilaian (LP), dan Buku Ajar Siswa. Setelah melalui tahap validasi ahli, dan uji coba lapangan, perangkat pembelajaran di atas dikategorikan baik.

Berdasarkan analisis statistik deskriptif diperoleh bahwa pembelajaran dengan melatihkan strategi belajar membaca mampu meningkatkan hasil belajar siswa dan didukung dengan minat siswa yang baik terhadap kegiatan pembelajaran.

\section{DAFTAR PUSTAKA}

Aiken, L.R. 1997. Psychological Testing and Assessment. Ninth Edition.

New York: McGraw Hill Companies.

Arikunto, S. 1998. Prosedur Penelitian, suatu

Pendekatan Praktek. Jakarta: PT. Rineka Cipta.

Borich, G.D. 1994. Observation Skill for Effective Teaching. New York: Macmillan Publishing Company.

Grounlund, N.E. 1985. Constructing Achievement Test . Third Edition.

New Jersey: Prencite-Hall.

Latjompoh, M. 2000. "Pengembangan Perangkat Pembelajaran Biologi SMU Pokok Bahasan
Sistem Koordinasi Berorientasi Strategi Belajar (Rehearsal, Elaborasi, Organisasi)". Tesis. Tidak Dipublikasikan. Surabaya: Universitas Negeri Surabaya.

Nur, M. 1998. Pengembangan Perangkat Pembelajaran dalam Rangka Menunjang Implementasi Kurikulum 1994 di Indonesia. Makalah yang Disampaikan pada Improving Teaching Proviciency of Indonesia Junior and Senior Secondary Teachers di SEAMEO-RSCAM. Penang Malaysia.

Nur, M. 2008. Pemotivasian Siswa untuk Belajar. Surabaya: Universitas Negeri Surabaya.

Qureshi. 2004. Instructional Design Models. [Online]. Tersedia: http://web2.uwindsor. $\mathrm{ca} /$ courses/edfac/morton/instructionaldesign.htm [22 Agustus 2010].

Slavin, R. E. 2008.Psikologi Pendidikan. Jakarta: PT Indeks. Thiagarajan, S., Semmel, D.S., Semmel, M.I. 1974.Instructional Development for Training Teachers of ExceptionalChildren.Minneapolis: Indiana University.

Westwood, P. 2004. Learning and Learning Difficulties.Acer Press. 